\title{
Early modern erudition and religious individualisation: the case of Johann Zechendorff (1580-1662)
}

\section{Introduction: an invitation to a funeral}

On 1 January $1630,{ }^{1}$ a baker by the name of Zacharias Zechendorff from the small Saxon town of Schneeberg in the Ore Mountains (Erzgebirge) wrote to his brother. After wishing him and his wife good health and peace for the coming year and commending them to God's care, he turned to the matter at hand:

\begin{abstract}
I cannot withhold from my heavy heart that God Almighty, whose council is secret and who alone is wise, has summoned our dear mother from this world on 31 December at the sixth hour, following her infirmity and numerous illnesses since Christmas Eve, and has released and redeemed her from this vessel of fear. Together with friends and relations, I have decided to bring her blessed corpse to burial, as is the custom (üblichen brauch nach) on Sunday 3 January and wish my dear brother and sister-in-law to attend this final show of respect and Christian duty. I also wish to convey my brotherly request that you both come to our late mother's house tomorrow or the following day, if possible, at the eleventh hour to pay your last respects. I would much rather be of service to my dear brother and my sister-inlaw under happier circumstances than this tearful occasion and faithfully commend them, together with ourselves, to the divine protection of the Almighty.
\end{abstract}

The recipient, Johann Zechendorff (1580-1662), was headmaster of the Latin school in nearby Zwickau, where the letter is now preserved in his Nachlass at the Zwickau Ratsschulbibliothek. ${ }^{2}$

1 Old Style.

2 Ratsschulbibliothek Zwickau (RSBZ) MS 172.6 fol. $38^{r-v}$. Meine willige Dienste neben Wunschung von Gott dem Allmächtigen eines glückligen, friedt vndt freudenreichen neuen Jahres frisches gesundten heiles sambt aller ersprießlichkeit an leib vndt seele bevorn EhrenvehsterAchtbarer vndt wohlgelehrter herr bruder, so wohl auch Erbare vndt Ehrentugendsamer frau Schwägerin, Derenselben kann ich aus betrübtem hertzen nicht vorhalten, wie Gott der Allmächtige nach seinen geheimen vndt allein weisen rath unsere liebe mutter nach ihrer großen vndt vielfältigen leibes schwachhait am heiligen Abendt iungst als 31 Decembris zu abendt umb 6 hora auß dieser welt abgefordert vndt aus den angst karren ausgespannet vndt erlöset. Wann i[c]h dann neben den andern freunden vndt Muhmen gänzlichen entschlossen bin, solches ihren seeligen leichnam künffigen Sontag als den 3 Januarij üblichen brauch nach zur erdten bestatten zu laßen, vndt aber den L[ieben] bruder sampt der fraw Schwägering ganz gerne bey solcher lezten ehrerzeigung vndt christlichen dienste ganz gerne sehen wißen vndt haben wollte, als glanget an dieselben mein 
Death notices and invitations to funerals are not an obvious place for historians to search for manifestations of religious individualisation. Read almost four hundred years later, the baker's letter to his brother offers us one of those archival moments when persons, long dead and forgotten, are 'given a voice'. Yet the relevance of this voice to the present publication may seem far from obvious. The baker of Schneeberg was inviting his brother to their mother's funeral. Whether or not the latter attended (we do not know), there is no reason to assume that the ceremony and the expressions of grief and solace surrounding Anna Zechendorff's death would have been performed and expressed in any fashion other than in conformity with seventeenth-century Lutheran practice. Through the accident of preservation among his brother's papers, Zacharias Zechendorff's voice has been preserved - in itself no mean achievement, as seventeenth-century bakers rarely leave a paper trail other than in parish registers and occasional legal records and wills. Unlike the doomed Meursault of Albert Camus' L'Étranger, the baker's reaction to his mother's death was embedded in a belonging to his society and its ritual and emotional norms. In terms of religious sentiment, his intention and wording, though personal, are unoriginal - nor was he aiming at originality or individualisation in any meaningful sense.

For the present inquiry, it is the recipient of the letter who is of interest. Johann Zechendorff, Zacharias' elder brother, was headmaster of the Latin school in Zwickau from 1617 until his death at the age of eighty-one in 1662. While his younger brother has subsided into posthumous oblivion, Johann Zechendorff has fared slightly better. In his fiftieth year, when he received the letter, the Zwickau schoolmaster was a respected, albeit minor, member of the Republic of Letters. He was, at the time, the author of several short works but above all was an enthusiastic student of oriental languages. A brief account of his scholarly pursuits will suffice, in order to shed light on this case of scholarship and religious individualisation. $^{3}$

brüderlich vndt schwägerlich bitten, wo es muglichen, sich morgen, oder folgendtes Tages umb 11 hora in der mutter seeligen behausung einzustellen, vndt Jhr inn diesen den letzten ehren dienst erzeigen vndt beweisen, [fol. $38^{\mathrm{V}}$ ] worfür ich dann den L[ieben] Bruder vndt frau Schwägering, iedoch lieber in frölichern, als solchen betrübten zustandt dienstwillig vndt sie neben uns allen Göttlicher protection vndt Allmacht ganz treulichen befehle. Datum Schneberg Den 1 Jan: A 1630. / Der L[iebe] Bruder / Williger / Zacharias Zechendorff / Bürger vndt Becker / Daselbst.

3 The following short account of Zechendorff's life is a much abridged version of that offered in Ben-Tov 2017a. 


\section{Johann Zechendorff: a seventeenth-century schoolmaster and Arabist}

Johann Zechendorff was born in 1580 in the Saxon town of Lößnitz in the Erzgebirge. His father, Michael Zechendorff, was a school teacher (in Lößnitz and later in nearby Schneeberg) and his mother Anna, née Hannauer, was the daughter of the mayor of Schwarzenberg. After the death of Zechendorff's father she remarried (Melzer 1716, 581). At first tutored by his father, Zechendorff commenced his studies at a series of Latin schools at the age of nineteen, visiting Aschersleben, Braunschweig, Eisleben, and the Latin school in Zerbst, before being recalled back home by his father. It seems that it was at the Latin school in Schneeberg that Zechendorff made his first significant acquaintance with oriental languages studying Hebrew, Aramaic, and Syriac. An acquaintance with Arabic, which was to prove his great passion, came only when he was in his early forties. After studying in Leipzig (1604-1608) he was appointed in 1610 as co-rector of the Latin school in Schneeberg, becoming its headmaster in 1614. In 1617 he was invited to head the municipal Latin school in Zwickau, where he remained headmaster for the rest of his long life, although in his final years he does not seem to have attended in person. At his death in 1662 he was survived by his second wife, Marien-Salome, née Götsen, but by none of his children. After some dealings, Zechendorff was succeeded as headmaster by his former pupil Christian Daum (1613-1687), a prominent scholar and pedagogue in his own right (Mahnke 2001; Ross 2015).

When Zechendorff assumed his post in Zwickau in 1617 he does not seem to have known any Arabic. His first works, extant in manuscript, deal with the instruction of Latin and bear the unlikely titles Methodus Cabbalistica, and Cabbalah Nova-Antiqua. Despite appearances, these dry manuals have nothing to do with Jewish mysticism but with a stringently systematic instruction of Latin, in the firm belief that such an approach would enable its swift and easy acquisition (schnell und leichtlich as Zechendorff puts it in his German writings). Though instruction in oriental languages was occasionally offered at German Latin schools $^{4}$ - mostly Hebrew, with occasional instruction in Aramaic (Chaldean), and Syriac - Zechendorff's belated but enthusiastic discovery of Arabic and its instruction in Zwickau are exceptional. It is to his study of Arabic, and of the Koran in particular, that Zechendorff owed his reputation in the seventeenthcentury Republic of Letters. In 1638 he published his Specimen Suratarum, the Arabic text of two short Suras (61 and 78) with an interlinear Latin translation and brief commentary, followed several years later by two further short Suras (101 and

4 See Ben-Tov 2017b for the Gymnasium Illustre in Hamburg. 
103) accompanied by a commentary based on the thirteenth-century Tafsir by Nāṣīr al-Dīn 'Abd Allāh b. 'Umar al-Bayḍāwī. ${ }^{5}$ These slim publications may seem unimposing to modern Arabists. However, they were a pioneering undertaking in an age when the Arabic text of the entire Koran was available in Europe only in manuscript (and these, for most scholars, not easily obtainable) and European students of Arabic like Zechendorff in Zwickau had very little in the way of reference books, with the important exception of Thomas Erpenius' Arabic grammar of 1613. Not surprisingly, Zwickau presses were not in possession of Arabic types. Instead of producing the Arabic text of Koranic specimens in Hebrew transliteration - a common practice among orientalists at the time - Zechendorff had one of his pupils prepare wooden types for him.

There is much to say about these two slim and pioneering scholarly publications (see Ben-Tov 2017a and 2017c); in the present context it will suffice to note that Zechendorff claimed in his correspondence to have translated the Koran in its entirety and that he had not been able to find a patron willing to pay for its publication. Clearly, Zechendorff's patrons had more urgent concerns on their mind during the Thirty Years War, which ravaged Saxony, and Zwickau in particular, whilst the town's schoolmaster was busy studying the 'Turkish bible'. Zechendorff occasionally mentions this complete Latin translation of the Koran to fellow scholars but it remained unpublished and, to the best of my knowledge, does not seem to have had an impact on contemporaries - if any indeed had read it. This led me, initially, to treat his claim with seasoned scepticism. A full Latin translation of the Koran, made directly from the Arabic original, whatever its philological merits, would have been a remarkable achievement at the time and was unlikely to disappear without a trace. The Zwickau schoolmaster, I thought, was neither the first nor the last scholar to exaggerate his scholarly achievements. I was wrong. Zechendorff's claim has recently been vindicated with Roberto Tottoli's discovery of the bilingual (Arabic/Latin) Koran manuscript held today at the Egyptian National Library and Archives in Cairo (Tottoli 2015). ${ }^{6}$ Zechendorff's translations of the four short Suras and his several other published works represent only a modest portion of his scholarly output. If we wish to understand his scholarship in situ and gauge its significance for an understanding of the possibilities of religious individualisation opened up by early modern erudition, we must turn to his manuscript Nachlass held at the Zwickau Ratsschulbibliothek. With this in mind, we return now to the letter he received from his brother in January 1630 informing him of their mother's departure.

5 Ben-Tov 2017a, 2017c; on the broader context see Malcolm 2012.

6 I am grateful to Roberto Tottoli for kindly allowing me access to a copy of this manuscript. 


\section{Scholarship and religious individualisation}

The relevance of this letter to the question of religious individualisation becomes apparent when one views the manuscript itself rather than a 'clean' transcript of its content. Like so many other letters addressed to him, Johann Zechendorff adorned the original with marginalia. The letter with its sad tidings reached Zechendorff about four years after he had acquired his own copy of the Koran. As mentioned above, this was no trivial acquisition. Until the printing of the Arabic text of the Koran by the Hamburg pastor Abraham Hinckelmann in 1694 and the epochal bilingual commentated edition by the Roman priest Ludovico Marracci four years later, European scholars wishing to study the Koran in the original had to procure a manuscript. There were various routes allowing for such acquisition, ranging from spoils from wars with the Ottoman Empire to trade in the Levant. We do not know how Zechendorff acquired his own copy. We do know, from comments he makes in passing in his works, that he had purchased it at great cost - an enormous investment for a badly paid schoolmaster. Regrettably, this copy is no longer to be found in Zwickau. We may assume either that Zechendorff sold it in his later years or that it was later sold by the school library, which had inherited his papers. Koran manuscripts in seventeenth-century Europe were valuable and, since the early modern study of the Koran in Zwickau did not outlive Zechendorff, there must have seemed little point in allowing an expensive codex to gather dust. On receiving the letter from his brother, his first Koranic publication was still eight years in the future (1638) but Zechendorff was already immersed in its study. At the bottom of the letter's first page, he noted in Arabic:

[...] He hath guided this woman on the road of the righteous and she believed in Allah 'Isa and sought refuge in him.

And further down:

He, in His mercy, helped her from this world into the Hereafter. And therefore, $\mathrm{O}$ all ye Turks, and O People of the Scripture, do not commit excess in your religion and do not say of Allah except the truth.

These Arabic notes are in fact a medley of paraphrased Koranic verses. What catches the eye at first glance is Zechendorff's assertion that the deceased woman believed in Allah and sought refuge in him, amended in an afterthought to 'Isa (the Arabic for Jesus). Of particular interest is also the closing exhortations to 'all ye Turks' to say nothing but the truth about God. This is a thinly disguised paraphrase of the Koranic verse 4:171: 'People of the Book, do not transgress the bounds of your religion. Speak nothing but the truth about God. The Messiah, 
Jesus son of Mary, was no more than God's apostle and His Word which He cast to Mary: a spirit from Him'. ${ }^{7}$ Sura 4, from which he was paraphrasing, is entitled The Women and opens, appropriately, with a call on believers to treat orphans justly. Zechendorff, it will be remembered, had just become an orphan himself - albeit a middle-aged one. Sura 4:171 is one of the central anti-Christian verses in the Koran, calling on the people of the Scripture (ahl al-kitāb), here meaning Christians, to not commit falsehoods about God, and thus not to claim that the pious prophet Jesus of Nazareth was the son of God, and to desist from referring to the Godhead as three-fold - unthinkable blasphemies from a Koranic point of view. Scribbled on the invitation to his mother's funeral, Zechendorff turns the tables on the original verse by calling the 'Turks' (a common Early Modern metonym for Muslims) to claim nothing but the truth about God - for a pious Lutheran a call to recognise Incarnation and the Trinity. If this was a dialogue with Muslims, it was one confined to the schoolmaster's own mind, a note penned on the notice of his mother's death. Above all, this and countless other notes in Arabic, made for personal edification, reveal that Zechendorff's study of the Koran, his visiting-card to the Republic of Letters, also had a personal and devotional aspect to it.

To stress the obvious: I am not suggesting that Zechendorff was in any way a crypto-Muslim nor that his enthusiastic and pioneering study of the Koran was an outlet for heterodox convictions or practices - e.g. an implicit endorsement of the antitrinitarian teachings of his Socinian contemporaries (cf. Mulsow 2010). The evidence we have suggests that he was a conformant seventeenth-century Lutheran, that he never intended to be anything else, nor was he mistaken for anything else by his contemporaries. And yet, when one examines his manuscripts, it becomes clear that his preoccupation with the Koran was (also) of a devotional nature - Lutheran but unconventional and profoundly individual.

There is more to this than a clever scribble by a self-taught Arabist. A comprehensive study of Zechendorff's Arabic marginalia and palimpsests, mostly in the letters preserved among his papers, may shed further light on his scholarship and its uses. It can here be noted that in some cases, as with the letter informing him of his mother's death, the Arabic notes are directly related to the content of the letter, while in other cases (probably most) he seems simply to be making use of free space on the letter page and unused versos. A case in point for the latter are his extensive Arabic quotes from the Arabic New Testament, preserved over numerous verso-pages of letters he received - beginning with Matthew 12:6,

7 All quotes from the Koran are taken from the English translation of N. J. Dawood 2006². 
Jesus' critique of the Pharisees and their 'hypocrisies' (Ms 172.6 fol. 110). ${ }^{8}$ In the same palimpsested letter convolute, we find Zechendorff paraphrasing Sura 33:1: 'Prophet, have fear of God and do not yield to the unbelievers and the hypocrites'. Ending with an Arabic paraphrase that lends the verse a Christian twist by reaffirming the Incarnation, this pious paraphrase is headed by the Latin title Alcoranus Christianus (Ms 172.6 fol. $70^{\mathrm{r}}$ ). Elsewhere, in the margins of an invitation to a wedding, we find a passionate address calling on the Jews (ahl al-yahüd) in pseudo-Koranic Arabic to embrace Jesus Christ as their saviour. Such outpourings of Christian piety scribbled on letters and ephemeral notes can, quite literally, be expanded a hundred-fold.

\section{The Koran and Lutheran personal edification}

Both in his miscellaneous notes, as well in works published and unpublished alike, the Zwickau schoolmaster is unequivocal in his commitment to his native Lutheranism and there is no reason to question the sincerity of his rejection of the Koran's antitrinitarian teaching. Yet his papers also reveal the profound affinity he felt to the Koran - if not to portions of its teaching then to its forceful expressions of monotheistic piety. Time and again we find Zechendorff marvelling at the language of the Koran and its expressive religious prowess. ${ }^{9}$ It is clear that he found Arabic, which he taught himself in his early forties, a congenial medium for expressing religious sentiment. Paraphrasing Koranic verses as expressions of Lutheran piety was something of a preoccupation of his and his papers also reveal his fondness for quoting the New Testament in Arabic. Most of all, we find him formulating his own prayers and rambling meditations in Arabic, ranging from a few sentences jotted down in the margins of invitations to weddings (and bearing no apparent relevance to the invitations) to religious 'essays' spanning the versos of several letters.

Zechendorff's discovery of Arabic and the bulk of his work as an orientalist coincided with the miseries of the Thirty Years War to which the inhabitants of Zwickau were repeatedly subjected - fighting accompanied by hunger and outbreaks of the plague (Herzog 1845). A virulent bubonic outbreak in 1626 claimed

8 The Arabic version of the New Testament was published in 1616 by the great Dutch Arabist Thomas Erpenius, Novum D.N. Iesu Christi Testamentum Arabice (Leiden, 1616).

9 From Zechendorff's comments elsewhere it is clear that he was also well aware of the poetical nature of the Koran. For the European discovery of the Koran as a work of religious poetry, see Loop 2009. 
the lives of 375 victims and occasioned an order from the Saxon Elector Johann Georg I for weekly penitential sermons and Catechism exams for adults as well as schoolchildren (Herzog 1845, 409).

Zechendorff's elaborate response to one bubonic outbreak, possibly that of 1626, is preserved in his Nachlass. Convinced, like many contemporaries, that the plague was an expression of divine wrath, the pious schoolmaster turned his attention to the Seven Penitential Psalms, which he read with his pupils in numerous languages. At the time, Zechendorff was offering Arabic lessons and was eager to introduce his pupils to the style and vocabulary of the Koran. ${ }^{10}$ This outpouring of piety at a time of dire affliction coupled with the eagerness of a learned Arabist to offer his pupils instruction in this language - a rarity at Europe's great centres of learning in the early seventeenth century, let alone at a Latin school! - gave birth to a striking work which was never published, and in all likelihood was never meant for publication: An Arabic paraphrase of the seven penitential psalms, i.e. in the style of and taken from the system of the Quran, which contains CXIII chapters, ${ }^{11}$ or rather from the Arab Cicero and in the Ismaelitic and regal Solomonic language: in pure and unadulterated speech set down rhythmically, with an interlinear Latin translation for the benefit of German students of Arabic, to allow them an easier access to the Quran. ${ }^{12}$ Zechendorff's German introduction to the work makes it clear that it is meant as a work of scholarship. He quotes some of the great scholars of his day, most notably the Leiden Arabist Thomas Erpenius, states his disagreement with others, and positions his work within the broader context of European scholarship since Robert of Ketton's twelfth-century translation of the Koran. Zechendorff was a fully-fledged member of the Republic of Letters and not unreasonably proud of his achievements. Yet at the same time, his 'Koranic paraphrase' of the Penitential Psalms, is clearly a devotional work, which fits in perfectly with his devotional Arabic practices scribbled at the margins of countless letters and notes.

As with almost all contemporary Europeans writing on the Koran, Zechendorff opens the introduction to the paraphrased Penitential Psalms with some

10 Possibly in private lessons (collegia privata).

11 This is a rare slip. As Zechendorff knew, the Quran has 114 chapters. In an undated letter to the Jena Orientalist Johann Ernst Gerhard the Elder (1621-1668), Zechendorff even offered an analysis of the short concluding Sura. Forschungsbibliothek Gotha (FBG) Chart. B. 451, fol. $132^{\mathrm{r}}$. 12 Septem Psalmorum poenitentialium Para-Phrasis Arabica id est stylo, \& ex Alcorani Systemate quod cxiii capita continet sive ex Cicerone Arabico \& Ismaelitica atque Lingua Salomonis regia: puris, merisque Loquutionibus appronatis Rhythmice [marg. add. Cum versione interlineari Latina] In Usum Arabicantium Germanorum: ut ad Alcorani Lectionem Aditus facilior patescat. Diligenti Lectione ac Meditatione a Iohanne Zechendorff $L L^{\text {arum }}$ Orientalium Cultore Conscripta. 
hostile comments. He notes that there is more eloquence (Reden $v[$ nd] Wortt) and substance (Res oder Realia) in the Psalter than in the 'monotone droning' of the 'book of the deluded Muhammad' (a book, it will be remembered, which he was studying intensively in those years). This stands in contrast to his subsequent assurance that the paraphrase, using Quranic verses as mosaic stones, '[...] is magnificently beautiful and ornate, set and recited in the regal Arabic tongue, as it [Arabic] is attributed to King Solomon, as its inventor, through the wisdom with which he was endowed by God. So, for the sake of this language, it is not to be contemned'. ${ }^{13}$

At the bottom of each page, Zechendorff quotes the 'paraphrased' psalm verse in Luther's German rather than in the original, stressing, to my understanding, the devotional nature of the work - he was certainly capable of quoting the psalter in the original Hebrew had he wished to. This is accompanied by several couplets of rhyming Arabic verses (made up by Zechendorff but attempting to emulate Koranic verses, sometimes using common Koranic phrases) which more or less approximate the tenor of each verse of the Penitential Psalms. To this is added an interlinear Latin translation. ${ }^{14}$ The resulting unpublished work was a mixture of devotional literature (however unusual) and an unconventional textbook to help pupils better understand the difficult language of the Koran - in itself an uncommon pedagogical goal in seventeenth-century Saxony! ${ }^{15}$ The work, not surprisingly, was never printed nor am I acquainted with any contemporary or later references to it. Despite the didactic background, the carefully written and nicely bound octavo volume has the air of a work of private devotion to it. Zechendorff's contemporaries, whether Protestant or Catholic, would have certainly understood the appeal of the Penitential Psalms - what is remarkable is that the Zwickau headmaster saw in the Koran, or in its phraseology, a kindred spirit which, to his mind, well expressed the sentiment, if not the content, of these Psalms. Nor is this elaborate work an isolated case. Thus, in writing to console the Marburg pastor Georg Teucher, whose wife Maria (a relative of Zechendorff's) had died in childbirth in 1654, Zechendorff concludes with a 'Koranic paraphrase' of Ps. 40.17: 'But I am poor and needy; yet the Lord thinketh upon me: thou art my help and my deliverer; make no tarrying, O my God'. He quotes in Arabic (in Hebrew transliteration) and in Latin translation what purport to be

13 Ibid. fol. 220v . Aber will es herlich schön, v. zierlich nach Arabischer königlicher Sprach / wie sie denn dem könig Salomoni, als dem Erfinder, nach seiner vom Gott verliehenen Weißheitt, zugeschrieben wirdt / gesetzet, $v$. geredetdt, so ist es der Sprachen halben, an ihr selbsten nicht zuverwerffen.

14 For a consideration of an example of this, see Ben-Tov 2017a, 58-60.

15 Septem Psalmorum poenitentialium Para-Phrasis Arabica, 223 . 
corresponding snippets from Suras 59:33 and 25, which, arranged together, read 'My misery lies heavily upon me, but my Lord prepares a feast in my honour. In him I have a guide. He suffices me as helper'. ${ }^{16}$ Further Arabic quotes from the Psalter are scattered among Zechendorff's myriad notes (e.g. Ms 172.6 fol. 98 ${ }^{\text {) }}$ and in the margins of his unpublished bilingual Koran there are numerous references to Psalm verses.

A further expression of Zechendorff's unusual approach to the Koran is offered by his first publication on the topic: a festive Latin oration he delivered at a graduation ceremony at the Latin school on 13 August 1627, with the title Fabulae Muhammedicae sive nugae Alcorani (Mohammedan Fables, or the Trifles of the Koran). The work offers a summary of and commentary on a number of episodes in the Koran that relate stories also known from the Old Testament. Both the account of the Koranic episodes and the schoolmaster's comment on them are delivered in Latin hexameter. ${ }^{17}$

The ostensible purpose of this work was to expose the mendacities of the Koran by presenting its version of several Old Testament events, in Latin verse, and pointing out the discrepancies. It is, however, hard to overlook the fact that most of the 'lies' Zechendorff excoriates are fairly trivial - e.g. censuring the unbiblical appearance of a raven in the Koranic account of Cain and Abel (5:27-31). Such instances arguably do more to stress what the Biblical and Koranic accounts have in common. It is also noteworthy that Zechendorff avoids here the numerous passages in the Koran which offer a religious point of view genuinely and significantly different from the understanding of religion he shared with his Zwickau audience. In the introduction, he likens the Koran to a work of oriental tapestry, striking in its colourful splendour and the variegated material from which it is woven. ${ }^{18}$ Put less colourfully, the Koran for Zechendorff was a medley

16 Miseria mea gravis mihi! Sed parat escsm honorem Dominus meus, mihi in eo director, sufficit ipse mihi auxiliator. באסי שדידן לי אלא אעתר אלרזק אלכרים רבי לי בה האדיאן כפַי הוַ לי נציראן. Zechendorff ends his condolences with a similar exercise on Ps. 4.17: 'I will both lay me down in peace, and sleep: for thou, Lord, only makest me dwell in safety', excerpting verses from Suras 7, 18 and 12.

17 A charming reminder of the immediate context, i.e. a graduation ceremony attended by local notables but also by talkative teenagers, is offered by Zechendorff's final remark before embarking on the first 'fable'. Ibid. $\mathrm{B} 2^{\mathrm{v}}$. Has ego dum refero strepera dictante Minerva/ Omnes nunc faveant, sint tranquillissima tecta:/ Garrula lingua suam non intermisceat odam.

18 Ibid. A2 ${ }^{\mathrm{v}}$. Quod sunt perstromata Babylonica, sive ut vocant tapetes Turcici, varietate quipped colorum a Phrygionibus variegate \& aucupicti: Jllud etiam est ALCORANUS ARABICUS, sive Liber ille, ex quo Turcae verbum Dei, \& suam Religionem se haurire sibi persuasum haben; per quem pie \& honeste hic vivere gestiunt, \& quo in tandem creduli se beari confidunt. 
of truth and falsehoods. ${ }^{19}$ True to form, the work is prefaced by an impassioned address to Muslims in Arabic and Latin, much akin to Zechendorff's marginal note to the letter of 1630 informing him of his mother's death:

O Turks and Arabs! If only you would separate that which is false from the book which you study, which are the fabulous parts, I have shown to you, and have written it down for you in Latin. [If you do so] you shall live in uprightness and shall be united with us in faith. ${ }^{20}$

The sentiment may have been sincere but at the same time I am not aware of any evidence to suggest that Zechendorff ever engaged in any missionary effort whatsoever or had any real interest in so doing. Apart from the obvious fact that converting Muslims would have been an unlikely undertaking in seventeenth-century Zwickau, if this piece of metric rhetoric were composed with an eye to proselyting, even beyond war- and plague-ridden Saxony, he would not have composed it in Latin hexameters. What captivated Zechendorff here were the parallels and affinities between the Koran and the Bible. This line of thought also informed his bilingual edition of and commentary on Suras 61 and 78 (1638). In the commentary to these short Koranic chapters, he offers an assessment of the truth value of each verse, depending on its conformity to teachings in the Christian Bible. In itself a standard way for seventeenth-century Christian scholars to study Islam (and indeed any foreign religion), what is striking is the considerable number of 'Christian truths' Zechendorff claims to have found in these two Suras.

Several years later Zechendorff would discover the importance of Muslim commentaries to the understanding of the Koran and would publish a further Koranic specimen, availing himself of the thirteenth-century commentary by Bayḍāwī, which he had recently obtained. This in itself is a significant development in his scholarship but his sustained fascination with the Koran, which is attested repeatedly in his manuscripts, was based rather on a sense of affinity than on a desire to study Islam in its own terms.

We turn finally to Zechendorff's most ambitious work, his unpublished translation of the entire Koran, recently discovered by Roberto Tottoli (Tottoli 2015; Glei 2016). An in-depth analysis of Zechendorff's approach to the task of translating the Koran is the subject of an ongoing research project in Bochum (Glei 2016).

19 Ibid. Sic modo vera \& sana invenimus posita: modo falsa \& mendacijs referta, nulloque sensus acumine aut argumentorum pondere, quod hominem Christianum vel leviter movere possit instructa: modo fabulosa atque absona veris sunt immista; modo de his, modo de illis confuse agens nomina tractat. [...] Jllis omnibus hactenus in authentico, \& autographo quodam Manuscripto Arabico cognitis a me eius gratia primum, ut linguam Arabicam aliquot modo (quum meo cortice natandum, viva Praeceptoris voce, destitute) familiarem mihi redderem.

20 Ibid. $4^{\mathrm{v}}$. 
The volume comprises the Arabic text, carefully copied out by Zechendorff, along with his interlinear Latin translation. The manuscript volume also contains a fair number of marginalia in the schoolmaster's distinctive handwriting. Many are of a philological nature, while others bear witness to a more personal, even devotional, reading. I would like to conclude with a brief consideration of a few instances.

The volume opens with several passages from other works of scholarship, which Zechendorff copied in his own hand by way of a preface to his ambitious work. Among these, interestingly, is a lengthy quote from Martin Luther's Table Talk, in which the Reformer discusses his translation of the Old Testament from Hebrew to German, stressing that 'I am no Hebrew according to grammar and rules' and that knowledge of languages was not in itself sufficient for the art of translation, which Luther sees as a particular divine gift and grace. ${ }^{21}$ What this is meant to indicate to readers about Zechendorff's Koran translation is open to speculation.

Not surprisingly, most of Zechendorff's marginalia to his Latin Koran translation are themselves in Latin. The few exceptions deserve special attention. One such we find in the margins alongside the opening verses of the fourth Sura (The Women):

You people! Have fear of your Lord, who created you from a single soul. From that soul He created its spouse and through them He bestrewed the earth with countless men and women. Fear God, in whose name you plead with one another, and honour the mothers who bore you. God is ever watching you. ${ }^{22}$

Zechendorff added a German paraphrase in the margin: Ihr sollt Gott anbeten mitt forcht. Er hatt den ersten Mann erschaffen $v[$ nd] von ihm das erste Weib, daher

21 Luther, Tischreden: Ich binn kein Ebreer nach der Grammatica v. Regeln, denn ich las Mich nirgent anbinden, sondern Ich gehe frey hindurch, Wenn einer gleich die Gabe der Sprachen hatt, $v$. verstehet sie, doch kann Er darumb nicht eine in die ander so bald bringen vnd wohl verdolmetschen. Dolmetschen ist ein solderliche Gnad vnd Gabe Gottes. Die 70. Griechische Dolmetscher/ so die Ebreische Bibel in die Griechische Sprach bracht haben sin im Ebreischen vnverfahren und vngeübt gewest/ ihr Dolmetschen ist sehr leppisch vnd vngereimpt / denn sie haben die Buchstaben / Wort vnd art zu reden verachtet / also/ das auch S. Hieronymi Versio vnd Verdolmetschen ihnen fürzuziehen ist. Wiewohl wer Hieronymum für ein Ebreer schilt / der thut ihm gewalt vnd vnrecht. Denn nach der Babylonischen Gefengnis ist diese Sprach so corrumpiert vnd verderbt/ das man sie nicht at widerumb können zu recht bringen/ Wenn Moses vnd die Propheten jetzt wider aufferstünden / so würden sie ihre wort / wie sie jetzund verdrehet sind / selbs nicht verstehehn.

22 Zechendorff translates this as: Eja homines, timete Dominum vestrum, qui vos creavit ex anima sola \& creavit ex illa conjugem suam \& \& diffudit ex illis duob[us] viros multos \& mulieres ergo colite Dominum quem petietis/interrogabitis [] eo \& matrices nam DEUS est vobis explorator. 
ihr alle herkommet, derwegen sollet ihr nicht hartt, noch vndanckbar sein gegen Ewern weibern, $v[$ nd] weill gott $v[n d]$ die engell den Waisen günstig sein, so sollet ihr Euch dieselben befohlen sein lassen. Esst von den ewrigen, $v$ [nd] nicht von dem, das ihnen zu gehöret, thut - here Zechendorff breaks off in mid sentence.

A tiny note scribbled in German over the title of Sura 70 is easily overlooked but instructive. Sura 70 ( $A l-M a^{\circ} \bar{a} r i j$, The ladder/ascending stairways) describes the Day of Judgment, with the evil doers' punishment and the reward of the just recounted after calling on believers to be patient ('Therefore conduct yourself with becoming patience. They think the Day of Judgment is far off: but We see it near at hand' 70:5-7). Over the Sura's title, Zechendorff jotted a note in miniscule German: Wie lang muß einer haben ehe er gen himmel steigt (How long must one wait, before one may ascend to heaven). This was probably added by an infirm, world-weary Zechendorff in his old age. Zechendorff, it is worth remembering, lived to be eighty-one - a feat of uncommon longevity in the seventeenth century. At his funeral in February 1662, his eulogiser, the Zwickau superintendent Gottfried Siegmund Peißker, admitted that Zechendorff no longer attended the Latin school in his final years but stayed at home praying all day, a sign of spiritual vitality in Peißker's eyes. Was Zechendorff pouring over his unpublished magnum opus as an act of the individualised piety of an unusual Lutheran Arabist? The countless pious ruminations scribbled in pseudo-Koranic Arabic on the versos of letters he had accumulated over the years suggest that at least some of the old schoolmaster's prayers, uttered while impatiently awaiting his ascent to Heaven, were spoken in Arabic.

\section{References}

\section{Primary sources}

Melzer, Christian. 1716. Historia Schneebergensis renovata. Das ist: Erneute Stadt- und Berg Chronica der im Ober-Erzt.Gebürge [...] Berg-Stadt Schneeber. Schneeberg.

Zechendorff, Johann. 1638. Specimen Suratarum, id est, Capitum aliquot ex Alcorani Systemate. Zwickau.

Zechendorff, Johann. [1626?]. Septem Psalmorum poenitentialium Para-Phrasis Arabica id est stylo, \& ex Alcorani Systemate quod cxiii capita continet sive ex Cicerone Arabico \& Ismaelitica atque Lingua Salomonis regia: puris, merisque Loquutionibus appronatis Rhythmice cum versione interlineari Latina In Usum Arabicantium Germanorum: ut ad Alcorani Lectionem Aditus facilior patescat. Diligenti Lectione ac Meditatione a Iohanne Zechendorff $L L{ }^{\text {arum }}$ Orientalium Cultore Conscrpita. Ratsschulbibliothek Zwickau, shelf-mark MS 18.4.29.

Zechendorff, Johann. 1627. Fabulae Muhammedicae sive nugae Alcorani [Zwickau]. 
Zechendorff, Johann [s.a.]. Suratae unius atque alterius textum ejusque explicationem ex commentario quodam arabe dogmata Alcorani, / verba maxima, minimaque explicante literatae genti ad felicius refutandum atque solidius dijudicandum, de versione tam Alcorani, quam commentatoris Muhammedanae religionis. Zwickau.

\section{Secondary sources}

Ben-Tov, Asaph. 2017a. 'Johann Zechendorff (1580-1662) and Arabic Studies in Zwickau's Latin School'. In The Teaching and Learning of Arabic in Early Modern Europe, ed. Jan Loop, Alastair Hamilton and Charles Burnett, Leiden: Brill. 57-92.

Ben-Tov, Asaph. 2017b. 'Orientalische Studien an Hamburgs Akademischem Gymnasium vom Anfang bis zur Berufung von Reimarus'. In Das Akademische Gymnasium zu Hamburg (gegr. 1613) im Kontext frühneuzeitlicher Wissenschafts- und Bildungsgeschichte, ed. Anselm Steiger (in collaboration with Martin Mulsow and Axel E. Walter), Berlin: De Gruyter. 119-35.

Ben-Tov, Asaph. 2017c. 'Johann Zechendorff'. In Christian Muslim Relation. A Bibliographical Hisotry. Volume 9: Western and Southern Europe (1600-1700), ed. David Thomas and Johan Chesworth, Leiden: Brill. 672-7.

Glei, Reinhold. 2016. 'A presumed lost Latin translation of the Qur'ān (Johann Zechendorff, 1632)', Neulateinisches Jahrbuch 18. 361-72.

Herzog, Emil. 1845. Chronik der Kreisstadt Zwickau. Bd. II: Jahresgeschichte. Zwickau. Zwickau: Höfer'sche Buchdruckerei.

Loop, Jan. 2009. 'Divine Poetry? Early Modern European Orientalists on the Beauty of the Koran', Church History and Religious Culture 89.4. 455-88.

Lutz Mahnke, Lutz. 2001. 'Christian Daum - ein Zwickauer “in ganz Europa berühmt”'. In Literarisches Leben in Zwickau im Mittelalter und in der Frühen Neuzeit, ed. Margarete Hubrath and Rüdiger Krohn, Göppingen: Kümmerle. 195-213.

Malcolm, Noel. 2012. 'The Study of Islam in Early Modern Europe: Obstacles and Missed Opportunities'. In Antiquarian and Intellectual Life in Europe and China, 1500-1800, Peter N. Miller and François Louis (eds.), Ann Arbor: Michigan University Press. 265-88.

Mulsow, Martin. 2010. 'Socinianism, Islam and the Radical Uses of Arabic Scholarship', Al-Qanțara 31.2. 549-86.

Ross, Alan. 2015. Daum's Boys: Schools and the Republic of Letters in early modern Germany. Manchester: Manchester University Press.

Tottoli, Roberto. 2015. 'The Latin Translation of the Qur'ān by Johann Zechendorff (1580-1662) Discovered in Cairo Dār al-Kutub’, Oriente Moderno 95. 5-31. 